\title{
An Overview of the Sustainable Development Plans of Hindurabi Island
}

\author{
AHMAD ABRISHAM CHI \\ Civil Engineering Department, Sharif University of Technology, Tehran, Iran.
}

ALI ASGHAR MOONESAN

Civil Engineering Department Tehran North Branch, Islamic Azad University, Tehran, Iran.

Email: asinnal349@yahoo.com

\begin{abstract}
The main objective of this research is to provide a framework by which decision-makers can evaluate and compare alternatives for sustainable development planning under uncertain dynamic future considering the risk and uncertainty associated with human judgment as well as the uncertain future. This approach combines the Delphi method, fuzzy set theory, and a discrete multi-criteria method based on prospect theory (TODIM). TODIM (an acronym in Portuguese for iterative MCDM) method is a particular multicriteria approach based on the prospect theory. A qualitative Delphi technique is used to identify a set of qualitative sustainability criteria and to rate the alternatives accordingly. The uncertainties and risks involved in information and judgment within the evaluation process are taken into account by using a hybrid approach called FTODIM (Fuzzy TODIM). The decision making model developed in this research examines three different techniques of aggregating the viewpoints of different decision-makers and explores how the aggregation technique affects the ranking of the alternatives. To demonstrate the potential application of the proposed approach, it is applied to the tourism development of Hendurabi Island in Persian Gulf, Iran for identifying the preferred plan among a set of alternative development plans. This research offers a novel development and application of the combined fuzzy MCDM and the Delphi approach to the Hendurabi Island's sustainable development.
\end{abstract}

Keywords: Sustainable Development, Sustainability Criteria, Island-based Tourism, Delphi process, Fuzzy MCDM, Prospect Theory, FTODIM, Hendurabi Island, Persian Gulf.

\section{Introduction}

Since the 1992 Earth Summit in Rio de Janeiro, the role of society's sustainable development has been observed and repeated at the 2002 World Summit on Sustainable Development in Johannesburg (United Nations, 2002). Without protection of the environment, sustainable development cannot be guaranteed. Environmental protection involves sustainable development, while environmental conditions support sustainable development. Realizing the need for ongoing economic and social growth, protecting and improving the state of the environment is the only way to generate and sustain the welfare of current and future generations. This is the key sustainable development issue. Economic and technical advancement in the last century has led to natural resource systems being neglected and deteriorated. In the Millennium Report to the General Assembly of the United Nations, in recognition of the growing burden that degraded ecosystems place on human well-being and economic development and the opportunity that better managed ecosystems provide for the achievement of poverty eradication and sustainable development goals (Elena \& Bennett, 2003). 
Sustainability is a process or state characteristic that can be maintained forever at a certain level. The work of the World Commission on Environment and Development, known as the Brundtland Commission in the 1980s, is a regular reference point for the notion of sustainability. The Commission described sustainable development in its study "Our Common Future" as "the development that meets the needs of the present without compromising the ability of future generations to meet their own needs." (WCED, 1987). This notion is of great importance in islands as our policymakers continue to strive to attain a balance between the integrated objectives of economic prosperity, social well-being and environmental stewardship.

Human well-being and advancement towards sustainability depend on enhancing Earth's ecosystem management to guarantee its conservation and sustainable use. But while requirements for ecosystem services are increasing, at the same moment, human activities are diminishing many ecosystems' ability to satisfy these requirements. Sound interventions in policy and management can often revert degradation of the ecosystem and enhance the ecosystem contributions to human well-being, but knowing when and how to intervene needs a significant knowledge of the ecological and social systems concerned.

\section{Hendurabi Island}

The Persian Gulf and its beautiful islands have been attracting visitors from Iran as well as neighboring countries for centuries. Some of the islands that are located in the Persian Gulf have already been developed for tourism while others remain undeveloped to this point. Kish, the main island, has already been established as an international tourism destination since 40 years ago and further developed and extended in recent decades. The Kish Free Zone Organization (KFZO) which operates the main island of Kish now intends to also develop neighboring Hendurabi Island.

Hendurabi is an Iranianisland in the Persian Gulf with an area of 22 square kilometers. The island is located 28 kilometers away from the popular Kish Island and its distance to the coastline is only 8 kilometers at $26^{\circ} 40^{\prime} \mathrm{N} 53^{\circ} 38^{\prime} \mathrm{E}$. The annual average temperature of the area is $27.5^{\circ} \mathrm{C}$ and the average of monthly maximum temperature is $38.2^{\circ} \mathrm{C}$. The year can be divided into two main seasons of hot ( 7 months) and cool (5 months), while August is the hottest and February is the coldest ones. The temperature fluctuation of the area is low; therefore, there is no probability of very low and freezing temperature.

There is almost no rainfall during 9 months of year and in those few times of raining, it happens as heavy showers and quick rainstorms (usually just two times a year). The average annual precipitation at Kish weather station is 12.4 millimeters. The area's weather is defined as hot and intensively humid. The humidity fluctuation of the area is low and the average percentage of relative humidity is $67.4 \%$. Evaporation rate studies are very significant due to water storage reservoirs and irrigation systems. High rate of humidity of the area leads to low percentages of evaporation. The lowest amount of evaporation belongs to January with $5.2 \mathrm{~mm}$ while the highest one is during June with $12.8 \mathrm{~mm}$. The prevailing wind flow blowing to the area is mainly from west and southwest. The wind direction is variable based on seasons and temperature. During hot season it blows from south and southwest while during autumn and winter the wind flow comes mostly from west and northwest. The annual maximum wind speed of the area is $14.3 \mathrm{~m} / \mathrm{s}$.

The form of Hendurabi looks like an oval with the large diagonal of 6.1- 7.7 km (from northwest to southeast) and small diagonal of $2.5-4.2 \mathrm{~km}$. The island is mainly flat with a smooth slope (1-1.5\%) to the sea. The altitude of the highest point from sea level is $23.33 \mathrm{~m}$. The coastal morphology is sandy with rocky shore. There are 16 land forms and 3 geomorphologic types of hill, plain and coastal lands at Hendurabi Island. The most prevailing land forms are: 1) Stony Outcrops, throughout more than $1 / 3$ of the island area, 2) Paleontological coral structures, throughout 20 percent of the island area. $95 \%$ of the island is almost flat, while 5\% has the slope of 5-25\% in 5 directions (NJP Consulting Engineers, September 2014). 
Hendurabi Island features a strong basis for developing tourism, mainly due to its natural beauty and location. One of its attractions is the wild and original nature of the island. Major tourism activities in Hendurabi Island focus on water activities as core theme, including:
$\checkmark$ Corral riffs journeys,
$\checkmark$ Snorkeling / diving,
$\checkmark \quad$ Swimming / beachside, and
$\checkmark \quad$ Fishing.

The nearest Population centers to the island are:

A. Chirouyeh village: settled in the main land, $5.85 \mathrm{~km}$ to the north-west of the island. Although no significant social-economic development has occurred in the area so far, closeness to the island can provide future probable access and communication opportunities to the main land.

B. Kish Island: as an important tourism and commercial center, $26.83 \mathrm{~km}$ to the east of the island.

C. Laavan Island: as a petroleum-industrial island $23.82 \mathrm{~km}$ to the west of the island.

Hendurabi Island accompanied with its coastal lands to the depth of $6 \mathrm{~m}$ under sea level, has been recognized as wildlife sanctuary by Iranian Environment Protection Supreme Counsel.

Figure 1 and Figure 2 show the Island location.

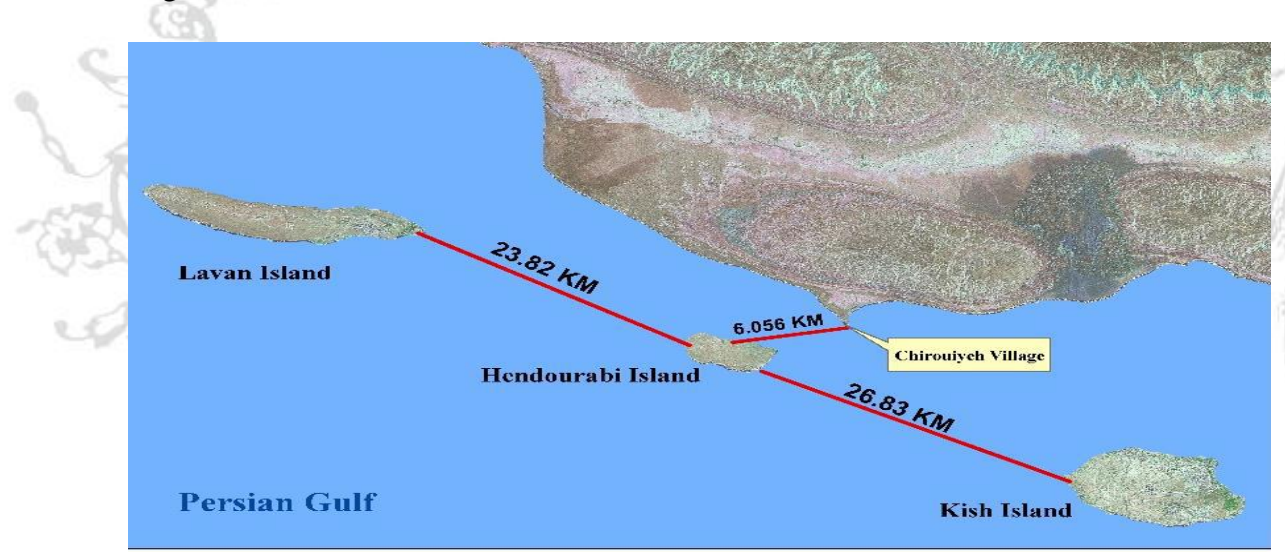

Figure 1: The island location in comparison to southern Iranian regions (NJP Consulting Engineers, 2014)

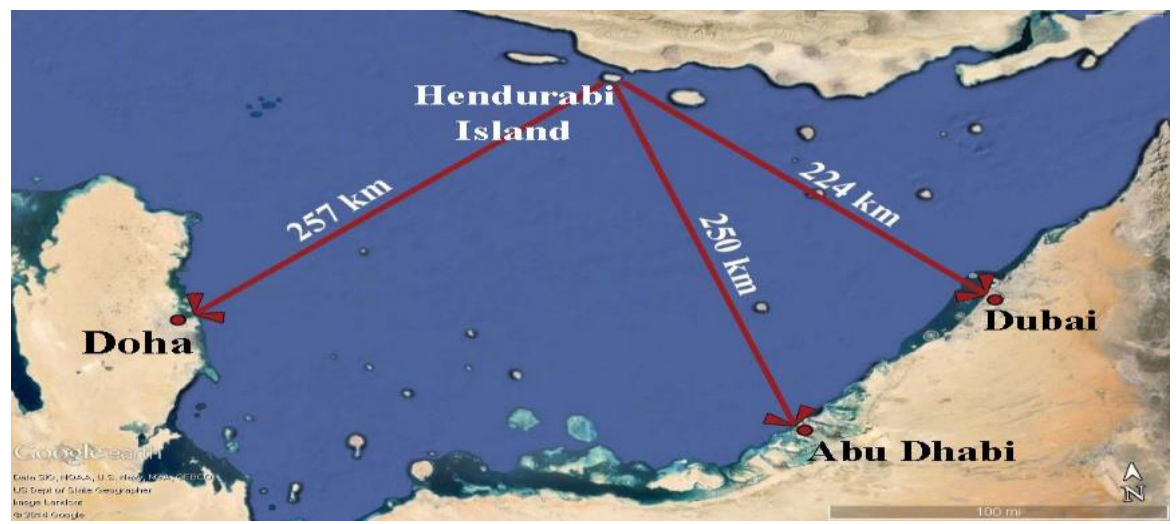

Figure 2: The island location in comparison to southern

Persian Gulf shorelines (NJP Consulting Engineers, 2014) 
Kish Island development model so far has been the classic economics-based approach. However, new developments in the sustainable approach to development must replace the classic pattern of development. It is believed that the prospects for further development of the Kish Free Zone including Hendurabi Island should be based on the new theoretical and scientific developments based on sustainable development approach. The Iranian government is creating opportunities for islands to learn from and to share innovations with their islands.

Considering various capacities in Kish Free Zone, Hendurabi Island will accelerate the development process in the region. Sustainable development model of human communities is the most efficient way of development, and many developing countries today are considering that; hence development plans of Hendurabi Island cannot be oblivious to that. The basic factors for sustainable growth in the long term, the long-term planning in this area has started, the fate of the island is not rich like other island in the country. Furthermore, development trend of the Kish Island shows its positive impact on the national development trend in the country, which could be accelerated due to the sustainable development policies of Hendurabi Island. Positive results and experiences of the implementation of sustainable development policies in Hendurabi Island can be used to other islands as well as the coastal areas.

Due to the suitable geographical location, Hendurabi Island has the high potential for tourism. Therefore, adoption of appropriate policies for development of this area according to the criteria of the sustainable development is very important. The KFZO aims to do that in an ecological, sustainable and profitable way while focusing on upscale tourism offerings in accordance with Iranian culture and Islamic law, i.e. the tourism offerings need to be halal. The analysis of global and regional tourism trends reveals that tourism is a strongly growing industry that is experiencing above-average growth rates in emerging markets such as the Middle East. Moreover, intraregional tourism constitutes the bulk of tourism activities in the Middle East. This makes the region an attractive area for investment in tourism, especially for tourism targeted at customers from the region itself.

In addition, the detailed best practice analysis of some tourism resorts in the region, provides many valuable insights. The analysis allows identifying success factors for tapping the touristic potential of a resort comparable to Hendurabi Island. The following success factors are considered among the most important:

$\checkmark \quad$ It should focus on upper middle and upper class income groups from the country itself as well as from the region as main target groups,

$\checkmark \quad$ It needs to be easily accessible from a major airport by convenient modes of transportation

$\checkmark$ It needs to offer a diversified range of facilities tailored to the target groups,

$\checkmark \quad$ It needs to combine water, wellness and further leisure activities,

$\checkmark$ The master planning of the resort should aim to achieve environmental sustainability and define key nodes that are easily accessible,

$\checkmark$ The financing of the resort should be based on a variety of public and private sources.

An assessment of potential target groups and their fit with the potential offerings of Hendurabi Island leads to the selection of domestic upper middle income groups as most promising, i.e. priority target group for the touristic development of Hendurabi Island. In addition, the domestic upper class income groups should be looked at as potential target group though not as the primary focus. In addition, the upper middle and upper class groups from neighboring countries constitute additional tourism potential, notably to fill the gaps in the low season. These groups are strongly growing in size and disposable income and can hence provide for a steadily rising demand.

From this analysis several implications and recommendations for the touristic development Hendurabi Island are derived. They include the following main points for the KFZO. 
$\checkmark$ Define the Unique Selling Proposition/Point (USP) of the island as a calm place for relaxation and wellness.

$\checkmark$ Focus on the upper middle and upper class from Iran as priority target group,

$\checkmark$ Attract further promising tourism groups in the vicinity of Iran to fill gaps in the low season,

$\checkmark$ Foster the development of different types of accommodation facilities (e.g. hotels, bungalows and villas),

$\checkmark$ Only allow the provision of activity offerings that are in accordance with the calm island character (e.g. scuba diving, picnicking and boat tours) but not noisy sports or attractions,

$\checkmark$ Only allow the provision of noiseless transport on the island,

$\checkmark$ Consider all implications of the position and length of the runaway of the airport as the current planning would not allow for mid-size planes with up to 100 passengers to land on Hendurabi,

$\checkmark$ Ensure the island's economic sustainability by aiming for a steady influx of revenues rather than large one-time revenues (e.g. leasing rather than selling land),

$\checkmark \quad$ Involve private investors in all investments that present a potentially attractive business case (e.g. hotels, activity offerings and utilities).

Tourism infrastructures, including accommodation facilities, restaurants and parks are parts of a development project, which is supposed to be run by an investment company as an executive agent of KFTZO. This organization has adopted the vision to develop Hendurabi Island as a place for high-quality tourism targeting not only domestic but also international tourists. An assessment of potential target groups of Hendurabi Island leads to the selection of domestic upper middle-income groups and the upper middle and upper class groups from neighboring countries as most promising tourists groups of the future. Hendurabi faces significant competition by some international destinations such as UAE with similar attractive seasons. But the offered services and activities in Hendurabi could potentially offer to reduce the impact of natural competition. Instead of forming competitions with larger neighboring tourist destinations, Hendurabi can be developed as a complementary element to the Kish Island. This proximity even allows to draw synergies by combining the value propositions of both islands. Therefore, tourists staying at Kish Island could come to Hendurabi Island for a single or multiple-day tours. Kish Island development model so far has been the classic economics-based approach. However, new developments in the sustainable approach to development must replace the classic pattern of development. It is believed that the prospects for further development of the Kish Free Zone including Hendurabi Island should be based on the new theoretical and scientific developments based on sustainable development approach. The Iranian government is creating opportunities for islands to learn from and to share innovations with their islands.

Considering various capacities in Kish Free Zone, Hendurabi Island will accelerate the development process in the region. Sustainable development model of human communities is the most efficient way of development, and many developing countries today are considering that; hence development plans of Hendurabi Island cannot be oblivious to that. The basic factors for sustainable growth in the long term, the long-term planning in this area has started, the fate of the island is not rich like other island in the country. Furthermore, development trend of the Kish Island shows its positive impact on the national development trend in the country, which could be accelerated due to the sustainable development policies of Hendurabi Island. Positive results and experiences of the implementation of sustainable development policies in Hendurabi Island can be used to other islands and also to some extent in coastal areas.

\section{Hendurabi Island Strategic Plan}

The southern Iranian water boundaries are accounted as interactional frontiers for making international relationship with other countries of the world. One of the most significant major spatial approaches of Iranian government is the strategy of development and investment in these areas by use of strategic geographical situation, and sustainable utilization of natural resources and potentials with special emphasis on the Persian Gulf islands. The strategy of substituted incomes as non-petroleum economy, require the Iranian coastal strip and islands, especially the Persian Gulf islands directing towards an economic and 
sustainable development.

Located in the Kish free zone domain, Hendurabi Island is the first island to be considered in this framework, and a comprehensive master plan for the Island with regard to its environmental vulnerability and values, was decided to be developed. The most important mission of this planning is realizing the slogan of 'Green Island' with the regional and global brand. For this purpose, a sustainable development focusing on mutual synergy between economic efficiency and environmental sustainability to meet the increasing demand for tourism and ecotourism activities at regional and international scales shall be regarded as a prominent principle for intervention (NJP Consulting Engineers, 2014).

The untapped nature of the island is among the special attraction of the island, but lack of infrastructure yet has not used this capacity. Tourism infrastructures including accommodation centers, restaurants, and parks are among development projects planned to be implemented by an investment company as the executive representative of Kish Free Trade Zone Organization (KFTZO).

Table 3: The major functional domains of Hendurabi Island from client's points of view (NJP Consulting Engineers, 2014).

\begin{tabular}{|c|c|c|}
\hline Environmental & $\begin{array}{l}\text { - Protection of environment and preventing } \\
\text { environmental pollution. } \\
\text { - Considering ecological capacity of the Island. }\end{array}$ & $\begin{array}{l}\text { - Establishment of activities related and } \\
\text { adaptive to the Island's natural features and its } \\
\text { carrying capacity. }\end{array}$ \\
\hline Technological & $\begin{array}{l}\text { - Realizing the slogan of "Green island". } \\
\text { - Developing clean and sustainable transport } \\
\text { system, with no environmental pollution. } \\
\text { - Utilizing new technologies to provide energy in } \\
\text { the Island. }\end{array}$ & $\begin{array}{l}\text { - Developing renewable energy generation } \\
\text { systems. } \\
\text { - Using electrical vehicle and rail way system. }\end{array}$ \\
\hline Economic & $\begin{array}{l}\text { - Emphasizing the role of Ecotourism. } \\
\text { - Reinforcement and enhancement of } \\
\text { connectivity and access to the Island from } \\
\text { tourists' departure points. }\end{array}$ & $\begin{array}{l}\text { - Arrangement of supporting services such as } \\
\text { recreational and residential facilities for } \\
\text { ecotourism. } \\
\text { - Developing airport and ports. }\end{array}$ \\
\hline $\begin{array}{l}\text { Legislative, } \\
\text { Executive and } \\
\text { Political }\end{array}$ & $\begin{array}{l}\text { - Anticipating executive mechanisms and } \\
\text { implementation requirements of the plan. } \\
\text { - Considering the place of Hendurabi village and } \\
\text { its impacts driven from and to the Island. }\end{array}$ & $\begin{array}{l}\text { - Precise description of project implementation } \\
\text { process and costs, accompanied with } \\
\text { Investment packages. } \\
\text { - Estimating population capacity of the } \\
\text { Hendurabi village and limiting its physical } \\
\text { boundary. } \\
\text { - Engagement of indigenous community } \\
\text { regarding its relative historical advantages. }\end{array}$ \\
\hline
\end{tabular}

\section{The Island Development alternative Plans}

According to the island's governing principles and requirements, four main roles have been identified as follows:
A. Nature tourism,
B. Tourism cluster - sea based activity,
C. Special ceremonies and events, and
D. Special residence and tourism. 
The scenario development process of the island development has been deduced from two directions: 1) based on the principles and requirements of the island's development, four main roles have been identified, and 2) the principles and requirements of island loading, resulted to three envisaged demographiceconomic options. However, the composition of each of the anticipated roles in the demographic- economic options remains unclear.

Environmental, economic, and social sustainability as the three principles of sustainable development are at the heart of the most fundamental school of thought governing the Island development. However, the degree of importance of each of the three concepts is different according to the importance of different foreseen role of the Island.

In order to combine these four roles with different aspects of sustainable development, three compound options have emerged, one for each environmental, economic and social aspects. The first option is called "environmental-driven development"; it puts the environment above all other aspects of the pyramid of sustainable development, and of the four mentioned role, the most important is the role of the "Nature tourism".

In contrast, the second option, hereinafter referred to as "social development", will address the social dimensions of development. It focuses primarily on the indigenous and island populations and specifically on the role of "Special ceremonies and events" of the island. Finally, "economic development - tourism" that focuses on income and economic self-sufficiency is focused mainly on the role of "Tourism cluster sea based activity" clusters and will be called "economic-tourism development". It is worth noting that in all three combination options, the role as "Special residency and tourism" is not identified solely as a functional role but as complementary one supporting other roles.

In addition to the combination of role options, three demographic-economic options have been proposed for the island, considering the existing facilities and capacities of the island, as well as the daily tourist transfer capacity from Kish Island. Accordingly, the number of basic and subsidiary jobs created and the population of the island are calculated. Each of the three demographic-economic options estimates a population of 1050,1650 , and 2250 daily incoming tourists (equivalent to $3,000,4,000$, and 5,000 daily tourist capacity), respectively. Their corresponding employment totals are 2003, 2467 and 3033 jobs respectively and the island population is 3710,4570 and 5618 , respectively.

The scenario development process of the island development has been deduced from two directions: 1) the principles and requirements of the identified island's roles and functions, and 2) the principles and requirements of island loading, leading to three envisaged demographic-economic options. Four main roles have been identified for the Island. From the second path, according to the. However, the relationship between each of the demographic and economic options proposed for the island is thus unclear, and the composition of each of the anticipated roles in the demographic options remain largely vague. Environmental sustainability, economic sustainability, and social sustainability as the three principles of sustainable development are at the heart of the most fundamental school of thought governing the Island development. However, the degree of importance of each of the three concepts is different according to the importance of different foreseen role of the Island.

The three development alternative plans of small-scale tourism development, moderate tourism development, and large-scale tourism development have been identified as described in Table (NJP Consulting Engineers, 2014). The first alternative, called "environmental-oriented development plan," emphasizes the environmental aspects and deals more with the activities which take place in the nature, whereas the third alternative, called "economic-tourism development plan," is based on economic selfsufficiency. The second alternative is between the first and third alternatives in terms of environmental and economic dimensions of sustainability. 
Table 4: Comparison of alternative plans (NJP Consulting Engineers, 2014)

\begin{tabular}{|lccc|}
\hline \multicolumn{1}{|c}{ Characteristic } & $\begin{array}{c}\text { Small-scale tourism } \\
\text { development }\end{array}$ & $\begin{array}{c}\text { Plan 2 } \\
\text { Moderate tourism } \\
\text { development }\end{array}$ & $\begin{array}{c}\text { Large-scale tourism } \\
\text { development }\end{array}$ \\
\hline Persons per km ${ }^{2}$ & 311 & 398 & 485 \\
\hline $\begin{array}{l}\text { Theoretical max. } \\
\text { number of people on } \\
\text { island (high-season } \\
\text { peak day, 100\% } \\
\text { occupancy) }\end{array}$ & $6901 \mathrm{p}$ & $8828 \mathrm{p}$ & $10762 \mathrm{p}$ \\
\hline $\begin{array}{l}\text { Total daily max. } \\
\text { number of tourists } \\
\text { (high-season/peak day) }\end{array}$ & 3080 & 4080 & 5080 \\
\hline $\begin{array}{l}\text { Total number of annual } \\
\text { visitors }\end{array}$ & 343090 & 457453 & 518211 \\
\hline $\begin{array}{l}\text { Total required building } \\
\text { land, ha }\end{array}$ & 1147 & 1357 & 1576 \\
\hline $\begin{array}{l}\text { Total number of } \\
\text { employees }\end{array}$ & 2077 & 2580 & 3088 \\
\hline $\begin{array}{l}\text { Hendurabi village } \\
\text { permanent residence }\end{array}$ & 3821 & 4675 & 5600 \\
\hline $\begin{array}{l}\text { Required developed } \\
\text { building) land per } \\
\text { tourist, m } / \mathrm{p}\end{array}$ & 372 & 333 & 310 \\
\hline
\end{tabular}

\section{Challenges and Threats}

Hendurabi Island has unique and fragile ecosystems due to the environmentally susceptible intertidal zone and coral reef ecosystems. Persian Gulf in general, is one of the areas that show serious declination in coral reefs. This rich ecosystem, defined as the rainforest of the sea, has ecological, economical, medical, recreational, and cultural values for communities. Human activity is one of the main factors that threaten the health of corals (Chunga, et al., 2019). Increase in sea temperature, sea level, and sea pH are broader threats that are associated with climate change. High salinity of water, oil pollution, water and air pollution, poor land practices, coastal development, recreation, ship grounding sedimentation, urban runoff toward the sea, coral mining, overfishing, and diving are reported as threats to the coral reefs in the region.

Environmental attributes which are related to tourism in Hendurabi Island include coral reefs, beach, water, vegetation, wildlife and fisheries. Coral reefs are one of the attributes that has received critical attention as facing visible effects of tourism activities.

\section{Coral Reefs}

Tourism activities are able to affect coral reefs either directly or indirectly. Direct effect implies to the intrusion to the coral community through accidental disturbance. This derives from coral breaking, boats colliding with reefs and damage from anchors. Snorkeling, diving and reef walking are other tourism activities that are believed to have a direct effect on coral breaking. The improper and uncontrolled manner in conducting these activities can lead to major damage on coral reefs.

The indirect effect of tourism on coral reef rises from the alteration of the water quality surrounding the reefs through pollution. Pollution of the water quality is usually linked to improper behavior of tourist, overcrowding of visitors, tourism infrastructure development and poor waste management. 


\section{Tourist Behavior}

Tourist behavior towards the impairment of coral reef in the island is believed to exceed other factors. Behaviors such as littering, reef walking at low tide, excessive water use and reef pickingare some of the negative behaviors of tourist that can seriously damage coral reefs.

\section{Water}

Water is another attribute of the island that receives an impact from tourism. An increase in the number of tourists equates to the increase in wastewater disposal from hotels and other buildings. Improper treatment of these waste waters could result it being discharged the sea. This would lead to devastating effects to the beach waters, ground water, abundance of fishes and water resources.

\section{Recreational Boating}

Recreational boating which can cause oil spills and release of heavy metals such as mercury and lead could degrade the water quality of islands. The effect is not only to water itself but the entire ecosystem surrounding the water. The growth of algae through the process of eutrophication could have a significant effect of the surrounding beach and coral reef communities. Tourists on board recreational boating and cruises also have a natural tendency of solid waste disposal to the water which can lead to devastating effects on water.

\section{Construction and Transportation}

Besides recreational boating, construction and transportation are actively conducted around the island area to support the increasing number of tourists. Runoff and waste deriving from these activities usually directed to waters due to improper discard. This could result to the increase in turbidity and suspended solids which directly affects the clarity of the water.

Turbidity refers are cloudiness in the water formed by silt, clay, organic, inorganic, chemical, plankton and other microorganism which scatters the entry of direct sunlight to the sea. Suspended solids are mineral and organic particles transported in the water in the form of silt and clay. Turbidity and suspended solids could significant effect on the decrease of production and abundance of plant materials, fish and fish food organism.

\section{Beaches}

Beach compromises another attribute of the island that receives significant impacts from tourism. It has been identified the one impact of tourism to the beaches, especially those caused by tourist asimproper disposal of solid waste that attracts animals, fungi, bacteria which leaves an uncomfortable smell in the surrounding areas. Poor solid waste management and high residential density further escalates the effect of solid waste on beaches.

The use of off-road vehicle activities by tourists on beaches has also been identified to have effects on the beach environment. Substances such oil and hydrocarbon released from these activities could lead to serious damage to the beach. Off-road vehicles could also have as vast effects on the fauna, vegetation and sensitive areas surrounding the beach.

Impacts of tourism on the beaches may also compromise the intrusion of sensitive areas and illegal and excessive fishing. Some other obvious impacts include improper feeding of animal which leads to them being poisoned to their death and the collection of corals, shellfish and other wildlife which could lead to an imbalance in the ecosystem. 


\section{Institutional Pressures}

Islands also face institutional pressures. These pressures include normative pressures to satisfy the environmental requirements of stakeholders and the environmental activities of industrial professional groups. Islands and theirs firms typically expect their resources to surpass environmental compliance and to develop efficient and product designs. Evidence shows that Islands and theirs firms from different types of economies react differently to sustainable challenges. The social, economic, and political factors that constitute the institutional structure of a particular environment can offer firms advantages for engaging in specific types of activities there. Moreover, businesses that receive institutional support tend to perform more efficiently. One of the institutional views that have emerged is that institutions have developed to a similar isomorphism across organizations even though the institutions have evolved differently and that institutions have shaped the behavior of agents (i.e., suppliers, customers, regulators, etc.).

\section{Earthquake}

Apart from the environmental impacts mentioned above, earthquake threat is notable, as located in the continental/oceanic convergent fault line.

\section{Research Findings}

In the context of sustainable development planning discussed in this research, the development alternatives could have only been described on the basis of a system comprising qualitative criteria faced to the uncertain future conditions and judgment uncertainties and risks. It is evident that these complexities in the decision-making process make it very difficult, if not impossible, to compare the alternatives directly. In order to select the best alternative in such system, on forming the group decision-making matrix, it is necessary to perform a fuzzy multiple criteria analysis of the alternatives combined with a group decisionmaking technique of data collection such as Delphi. More specifically, the combined application of FTODIM framework and Delphi process for sustainable development of Hendurabi Island has had important characteristics as outlined below:

- This study revealed the social, economic, and environmental dimensions and criteria of sustainable development in Hendurabi Island;

- Bringing light into some of the elements that constitute the identity of Hendurabi Island directly related to the value given to the Island;

- It also showed in what ways real world sustainability planning and decision making problems are uncertain and how they could be addressed;

- A novel development and application of the combined fuzzy MCDM and the Delphi approach to small island sustainable development;

- The feedbacks reveal that this model is quite reliable in selecting small island development alternative and can improve the efficiency of decision-making process;

- Identifying and including important social, economic, and environmental criteria, which are missing in previously mentioned literature, by Delphi process;

- Provide a framework by which decision-makers can evaluate and compare alternatives for sustainable development planning under uncertain dynamic future considering the risk and uncertainty associated with human judgment as well as the uncertain future;

- With regard to the little studies in this area on one hand and more coastal development plans in the country and worldwide on the other hand, the proposed approach and methodology can help the planners to make better informed and effective decisions; and

- Offering an approach and methodology applicable to similar cases.

While good progress has been made with the current study, there are some issues that could be addressed to improve the outcome of the modeling tool with future studies: 
- Technology, science and capacity building are major pillars of the means of implementation of the sustainability agenda. Therefore, identifying which available and future policies and technologies are the most critical for improving the sustainability of Hendurabi Island, which are nice-tohave's, and which can become serious distractions. Furthermore, the means of implementation of Hendurabi Island's development plan could nevertheless provide an opportunity to address some of the gaps hindering the facilitation and transfer of these technologies.

- Applications of the developed approach in this research to more real environmental decision making problems with real decision makers are urgently needed to demonstrate the efficacy of the fuzzy systems approach for solving real world problems.

- Investigating the feasibility of other fuzzy Delphi methods such as Cloud Delphi model (CDM) in capturing uncertainties of subjective cognition and judgmental inputs and complex, large, multidisciplinary real-life decision problems;

- Exploring how a future and scenario analysis offers a framework that include future in present decision-making for developing a sustainable plan, considering the uncertainties and dynamics of the natural and human drivers of the future and how the consideration of multiple possible futures contributes in robustness of planning;

- Adding the capability of sensitivity analysis to the FTODIM model to calculate the change in the final score of alternatives in light of changing in the weight of particular criteria and rank of alternatives, immediately;

- Vulnerability assessments to understand impacts of climate change on ocean and coastal socioecological systems and the economies and livelihoods as well as recognizing the feasibility or suitability considerations relevant for implementing coastal adaptation strategies; and

- It is also essential to devise methodologies for bridging the gap between climate science, law and policy to advance coastal and marine adaptation planning.

\section{Conclusion}

In this research, a fuzzy multi-criteria decision-making approach with due consideration of the uncertainties and risks is developed to assess and analyze the alternatives of sustainable development projects. This study applied Delphi survey which is becoming increasingly popular. The sustainability criteria have been identified due to their roles and natures in relation to tourism and sustainable development in a Delphi process. Most of the time, the experts cannot express judgment especially subjective expertise in accurate numerical terms but use linguistic labels or fuzzy preferences. The use of linguistic labels or fuzzy numbers make expert's judgment more reliable and informative for decision making. As crisp decision making methodologies with precise numerical values in the group decision making procedures giving the experts large burdens and making the decision making processes not be easily implemented, the fuzzy multicriteria decision making (FMCDM) has become an important field of management science, decision science and operational research.

One of the appropriate multi-criteria decision making methods under fuzzy sets is FTODIM. This method uses the pair comparison between the criteria in order to remove the odds led by comparisons using the simple technical resources. FTODIM makes it possible to perform the value judgments on a linguistic scale using the hierarchy of norms, fuzzy value judgments and interdependence of alternatives. The decision matrix includes the alternatives and criteria. FTODIM method is a particular multi-criteria approach based on the prospect theory. The model is based on a valid experimental model, which describes how people in the face of risk make the effective decisions. In prospect theory, the value function is similar to the cost and benefit function. The multi-criteria value function is formed by mathematical models that reproduce the cost and benefit function. The global multi-criteria value function integrates all measures of cost and benefit. The formation of FTODIM is included cost and benefit relations in the multi-criteria function. In this study, the authors consider three development alternatives and 23 criteria whereby 11 of these criteria are cost type and the others are profit type. 


\section{References}

Altuntas, S., Dereli, T. \& Yilmaz, M. K., 2012. Multi-criteria decision making methods based weighted SERVQUAL scales to measure perceived service quality in hospitals: A case study from Turkey. Total Quality Management \& Business Excellence, Volume 23, p. 1379-1395.

Avella, J. R., 2016. Delphi panels: Research design, procedures, advantages, and challenges. International Journal of Doctoral Studies, Volume 11, pp. 305-321.

Azimi, N. A., 2009. Tourism Management and Ecologic Sustainability (In Farsi). Environmental Sciences Journal, National Science Policy Research Center, 6.(4)

Baran, P., 1964. On distributed communications: Introduction to distributed communications networks. Santa Monica: The Rand Corporation.

Benedicto, J., 2014. Identity and decision-making for sustainability in the context of small islands. Journal of Integrated Coastal Zone Management, 14(2), pp. 199-213.

Benoit, V. \& Rousseaux, P., 2003. Aid for aggregating the impacts in Life Cycle assessment. The International Journal of Life Cycle Assessment, 8.(74)

Brans, J. \& Mareschal, B., 2005. Promethee Methods. In: Multiple Criteria Decision Analysis: State of the Art Surveys. New York: Springer.

Bruneau, M. et al., 2003. A framework to quantitatively assess and enhance the seismic resilience of communities. EERI Spectra Journal, 19(4), pp. 733-752.

Bunruamkaew, K. \& Murayama, Y., 2012. Land Use and Natural Resources Planning for Sustainable Ecotourism Using GIS in Surat Thani, Thailand. Sustainability, 4(3), p. 412-429.

Cao, Q.-W. \& Wu, J., 2011. The extended COWG operators and their application to multiple attributive group decision making problems with interval numbers. Applied Mathematical Modelling, 35(5), pp. 2075-2086.

Chen, H.-S., 2015. The Establishment and Application of Environment Sustainability Evaluation Indicators for Ecotourism Environments. Sustainability, 7(4), p. 4727-4746.

Chen, N. X. Z. \& Xia, M., 2013. Interval-valued hesitant preference relations and their applications to group decision making. Knowledge-Based Systems, Volume 37, pp. 528-540.

Chunga, A. et al., 2019. Translating resilience-based management theory to practice for coral bleaching recovery in Hawaii. Marine Policy, Volume 99, pp. 58-68.

Cinelli, M., Coles, S. \& Kirwan, K., 2014. Analysis of the potentials of multi criteria decision analysis methods to conduct sustainability assessment. Ecological Indicators, Volume 46, p. 138-148.

Cioca, L.-I.et al., 2015. Sustainable development and technological impact on $\mathrm{CO} 2$ reducing conditions in Romania. Sustainability, 7(2), pp. 1637-1650.

Cioce, C., Bona, M. \& Ribeiro, F., 2007. Community tourism: montanha beija-flor dourado pilot project (microbasin of the sagrado river, Morretes, Paraná). Turismo-Visao e Açao, 9(2), pp. 249-266.

Conrad, E. \& Cassar, L., 2014. Decoupling Economic Growth and Environmental Degradation: Reviewing Progress to Date in the Small Island State of Malta. Sustainability, 6(10), p. 6729-6750.

Daldeniz, B. \& Hampton, M., 2010. VOLUNtourists versus volunTOURISTS: a true dichotomy or merely a differing perception? London: Routledge.

Dalkey, N. \& Helmer, O., 1963. An experimental application of the Delphi method to the use of experts. Management Science, 9(3), p. 458-467.

Das, M. \& Chatterjee, B., 2015. Ecotourism: A panacea or a predicament? Tourism Management Perspectives, Volume 14, p. 3-16.

De Montis, A. et al., 2005. Assessing the quality of different MCDA methods. Abingdon: Routledge.

De-Miguel-Molina, B., de-Miguel-Molina, M. \& Rumiche-Sosa, M. E., 2014. Luxury sustainable tourism in small island developing states surrounded by coral reefs. Ocean \& Coastal Management, Volume 98, pp. 86-94.

Dempsey, N., Bramley, G., Power, S. \& Brown, C., 2011. The social dimension of sustainable development: defining urban social sustainability. Sustainable Development, 19(5), pp. 289-300.

Dhami, S. \& Al-Nowaihi, A., 2007. Why do people pay taxes? Prospect theory versus expected utility theory. Journal of Economic Behavior \& Organization, 64(1), p. 171-192. 
Donovan, F., 2009. Our uncertain future: Can good planning create sustainable communities, s.l.: UNIVERSITY OF ILLINOIS AT URBANA-CHAMPAIGN.

Duran, D., Gogan, L., Artene, A. \& Duran, V., 2015. The components of sustainable development - a possible approach. 4th World Conference on Business, Economics and Management, WCBEM, Procedia Economics and Finance, s.n.

Eliasson, E., 2007. In Search of the Holy Grail: A Case Study of the Implementation of Sustainable Practices in the Accommodation Industry in Siem Reap, Cambodia, s.1.: Handelshögskolan vid Umeå universitet.

European Commission, 2015. Science for Environment Policy. Indicators for sustainable cities. In-depth Report 12.

Eusébio, C., Vieira, A. \& Lima, S., 2018. Place attachment, host-tourist interactions, and residents' attitudes towards tourism development: the case of Boa Vista Island in Cape Verde. Journal of Sustainable Tourism, 26(6), p. 890-909.

Eusébio, C., Vieira, A. L. \& Lima, S., 2018. Place attachment, host-tourist interactions, and residents' attitudes towards tourism development: the case of Boa Vista Island in Cape Verde. Journal of Sustainable Tourism, 26(6), pp. 890-909.

Fernandes, J. P., Freire, M., Guiomar, N. \& Gil, A., 2017. Using modeling tools for implementing feasible land use and nature conservation governance systems in small islands - The Pico Island (Azores) casestudy. Journal of Environmental Management, Volume 189, p. 1-13.

Hashemi, H., Bazargan, J. \& Mousavi, S., 2013. A Compromise Ratio Method with an Application to Water Resources Management: An Intuitionistic Fuzzy Set. Water Resources Management, pp. 1-23.

Hashemkhani Zolfani, S., Maknoon, R. \& Zavadskas, E., 2015. Sustainable tourism: a comprehensive literature review on frameworks and applications. Economic Research-Ekonomska Istraživanja, 28(1), pp. 1-30.

Indicators for sustainable cities, 2015. Science for Environment Policy, In-depth Report 12, Bristol: the Science Communication Unit, UWE.

Jahan, A. \& Edwards, K. L., 2015. A state-of-the-art survey on the influence of normalization techniques in ranking: Improving the materials selection process in engineering design. Materials \& Design, Volume 65 , p. 335-342.

Jamal, T., Camargo, B. \& Wilson, E., 2013. Critical Omissions and New Directions for Sustainable Tourism: A Situated Macro-Micro Approach. Sustainability, 5(11), p. 4594-4613.

Kahneman, D. \& Tversky, A., 1979. Prospect theory: An analysis of decision under risk. Econometrica, Volume 47, p. 263-292.

Kaufmann, A. \& Gupta, M., 1988. Fuzzy mathematical models in engineering and management science. Amsterdam: North-Holland.

Lee, T. H., Jan, F. H. \& Huang, G. W., 2015. The influence of recreation experiences on environmentally responsible behavior: The case of Liuqiu Island, Taiwan. Journal of Sustainable Tourism, 23(6), p. 947-967.

Lee, T., Jan, F.-H. \& Tseng, C. e. a., 2017. Segmentation by recreation experience in island-based tourism: a case study of Taiwan's Liuqiu Island. Journal of Sustainable Tourism, 26(3), p. 362-378.

Liao, H. \& Xu, Z., 2013. A VIKOR-based method for hesitant fuzzy multi-criteria decision making. Fuzzy Optimization and Decision Making, 12(4), pp. 373-392.

Lin, W., Li, Y., Li, X. \& Xu, D., 2018. The Dynamic Analysis and Evaluation on Tourist

Liu, P., Rong, L. \& Teng, F., 2019. The evaluation of ecosystem health based on hybrid TODIM method for Chinese case. Technological and Economic Development of Economy, pp. 1-29.

Luo, S., Zhang, H., Wang, J. \& Li, L., 2019. Group decision-making approach for evaluating the sustainability of constructed wetlands with probabilistic linguistic preference relations. Journal of the Operational Research Society, pp. 1-17.

Mardani, A., Jusoh, A. \& Zavadskas, E. K., 2015. Fuzzy multiple criteria decision-making techniques and applications - Two decades review from 1994 to 2014. Expert Systems with Applications, Volume 42, p. $4126-4148$. 
Marin, C., Dorobanțu, R., Codreanu, D. \& Mihaela, R., 2012. The Fruit of Collaboration between Local Government and Private Partnersin the Sustainable Development Community Case Study: County Valcea. EconomyTransdisciplinarity Cognition, p. 93-98.

Marion, J., Leung, Y.-F. \& Eagleston, H. e. a., 2016. A Review and Synthesis of Recreation Ecology Research Findings on Visitor Impacts to Wilderness and Protected Natural Areas. Journal of Forestry, 114(3), p. 352-362.

Mercer, J., Kelman, I., Alfthan, B. \& Kurvits, T., 2012. Ecosystem-Based Adaptation to Climate Change in Caribbean Small Island Developing States: Integrating Local and External Knowledge. Sustainability, 4(8), p. 1908-1932.

Miller, D. \& Starr, M. K., 1969. Executive Decisions and Operations Research. Englewood Cliffs, NJ: Prentice-Hall.

Mousavi, S., Jolai, F. \& Tavakkoli-Moghaddam, R., 2013a. A fuzzy stochastic multi-attribute group decision-making approach for selection problems. Group Decision and Negotiation, 22(2), pp. 207233.

Mousavi, S., Torabi, S. \& Tavakkoli-Moghaddam, R., 2013b. A hierarchical group decision-making approach for new product selection in a fuzzy environment. Arabian Journal for Science and Engineering, 38(11), pp. 3233-3248.

Moyle, B., Weiler, B. \& Croy, G., 2013. Visitor's perceptions of tourism impacts: Bruny and Magnetic Islands, Australia. Journal of Travel Research, 52(3), pp. 392-406.

Murugadas Ramdasa, B. \& Badaruddin, M., 2014. Impacts of tourism on environmental attributes, environmental literacy and willingness to pay: A conceptual and theoretical review Procedia. s.1., 5th Asia Euro Conference 2014. Social and Behavioral Sciences 144.

Neuts, B., Romao, J., Nijkamp, P. \& Shikida, A., 2014. A Quality Assessment of Tourist Information. AlmaTourism, 5.

Nguyen, Q., 2016. Linking loss aversion and present bias with overspending behavior of tourists: Insights from a lab-in-the-field experiment. Tourism Management, Volume 54, p. 152-159.

Nickerson, N. P., Jorgenson, J. \& Boley, B. B., 2016. Are sustainable tourists a higher spending market? Tourism Management, Volume 54, p. 170-177.

NJP Consulting Engineers, 2014. Strategic Plan of Hendurabi Island.

Ok, K., 2006. Multiple criteria activity selection for ecotourism planning. Turkish Journal of Agriculture and Forestry, 30(2), pp. 153-164.

Pearce, D., Markandya, A. \& Barbier, E., 1989. Blueprint for a Green Economy. London: Earthscan .

Popescu, G. et al., 2017. A CROSS-SECTIONAL STUDY OF SUSTAINABILITY ASSESSMENT. Economic Computation \& Economic Cybernetics Studies \& Research, 51.

Pusiran, A. \& Xiao, H., 2013. Challenges and community development: A case study of homestay in Malaysia. Asian Social Science, 9.

Qin, Q. et al., 2017. A TODIM-based multi-criteria group decision making with triangular intuitionistic fuzzy numbers. Applied Soft Computing, Volume 55, p. 93-107.

Rodríguez, R., Martínez, L. \& Herrera, F., 2013. A group decision making model dealing with comparative linguistic expressions based on hesitant fuzzy linguistic term sets. Information Sciences, Volume 241, pp. $28-42$.

Stone, M. T. \& Nyaupane, G. P., 2017. Protected areas, wildlife-based community tourism and community livelihoods dynamics: spiraling up and down of community capitals. Journal of Sustainable Tourism, 26(2), p. 307-324.

Strack, P. \& Viefers, P., 2014. Regret and economic decision-making, s.1.: VOX CEPR Policy Portal.

Strack, P. \& Viefers, P., 2014. Regret and economic decision-making, s.1.: VOX CEPR Policy Portal.

Thompson, B. S., Gillen, J. \& Friess, D. A., 2017. Challenging the principles of ecotourism: insights from entrepreneurs on environmental and economic sustainability in Langkawi, Malaysia. Journal of Sustainable Tourism, 26(2), p. 257-276.

Triantaphyllou, E., Shu, B., Nieto Sanchez, S. \& Ray, T., 1998. Multi-Criteria Decision Making: An Operations Research Approach. New York: John Wiley \& Sons. 
United Nations, 1987. Our Common Future / Brundtland Report. Oxford University Press ed. Oxford: United Nations World Commission on Environment and Development.

United Nations, 2015. How to Make Cities More resilient, UNITED NATIONS, A Contribution to the Global Campaign, 2010-2015.

Vander-Merwe, I. \& Vander-Merwe, J., 1999. Sustainable development at the local level: An introduction tolocal agenda 21, s.1.: Pretoria: Department of environmental affairs and tourism.

Vare, P. \& Scott, W., 2007. Learning for a change exploring the relationship between education and sustainable development. Journal of Education for Sustainable Development, pp. 191-198.

Wang, L., Zhong, L., Zhang, Y. \& Zhou, B., 2014. Ecotourism Environmental Protection Measures and Their Effects on Protected Areas in China. Sustainability, 6(10), p. 6781-6798.

Wątróbski, J., Jankowski, J. \& Ziemba, P. e. a., 2018. Generalised framework for multi-criteria method selection. Omega: The International Journal of Management Science.

Xia, H., Li, D., Zhou, J. \& Wang, J., 2006. Fuzzy LINMAP method for multiattribute decision making under fuzzy environments. Journal of Computer and System Sciences, 72(4), pp. 741-759.

Xia, M., Xu, Z. \& Chen, N., 2013. Some hesitant fuzzy aggregation operators with their application in group decision making. Group Decision and Negotiation, 22(2), pp. 259-279.

Xu, Z. \& Zhang, X., 2013. Hesitant fuzzy multi-attribute decision making based on TOPSIS with incomplete weight information. Knowledge-Based Systems, Volume 52, pp. 53-64.

$\mathrm{Xu}, \mathrm{Z}$., 2007. Intuitionistic preference relations and their application in group decision making. Information Sciences, 177(11), pp. 2363-2379.

Yang, X., Zeng, L. \& Zhang, R., 2012. Cloud Delphi method. International journal of

Zhang, N. \& Wei, G., 2013. Extension of VIKOR method for decision making problem based on hesitant fuzzy set. Applied Mathematical Modelling, 37(7), pp. 4938-4947.

Zimmermann, H.-J., 1978. Fuzzy programming and linear programming with several objective functions. Fuzzy Sets and Systems, Volume 1, p. 45-55. 